\title{
Spremnost djece za školu iz perspektive učitelja
}

\author{
Sandra Kadum* \\ sandra.kadum@unipu.hr \\ https://orcid.org/0000-0002-8441-0896 \\ Dijana Drandićs* \\ ddrandic@iv.hr \\ https://orcid.org/0000-0003-0645-4698 \\ Lorena Lazarić ${ }^{* * * * *}$ \\ lorena.lazaric@unipu.hr \\ https://orcid.org/0000-0002-4305-2025
}

\author{
https://doi.org/10.31192/np.19.3.8 \\ UDK: $37.015 .3-053.4$ \\ 37.064 .2 \\ 303.423:37 \\ Prethodno priopćenje / \\ Preliminary communication \\ Primljeno: 2. ožujka 2021. \\ Prihvaćeno: 12. svibnja 2021.
}

Cilj rada bio je ispitati stavove učitelja razredne nastave o spremnosti djece za školu s naglaskom na predčitalačke i predmatematičke vještine djece. U istraživanju su sudjelovala 362 ispitanika, učitelja razredne nastave iz osnovnih škola u Republici Hrvatskoj. Istražili smo i utvrdili da učitelji kao najvažnije izdvajaju vještine koje djeca trebaju steći prije polaska u školu: pravilno držanje olovke, odnosno pisaćeg pribora i čisto izgovaranje svih glasova kao predčitalačke vještine te prepoznavanje boja i razumijevanje prostornih odnosa (ispred, iza, gore, dolje, na, u, lijevo, desno) kao predmatematičke vještine. Nije utvrdena statistički značajna razlika u stavovima učitelja prema predčitalačkim vještinama u odnosu na godine radnog iskustva u nastavnoj djelatnosti, ali je utvrđena statistički značajna razlika između većine čestica predmatematičke vještine. $U$ tom kontekstu, preporuke za buduća istraživanja odnose se na spremnost škola za djecu i spremnost obitelji i zajednica za školu te njihovu povezanost sa sociokulturnim kontekstom.

Ključne riječi: predčitalačke i predmatematičke vještine, predškola, spremnost za školu, učenik, učitelj.

* Doc. dr. sc. Sandra Kadum, Sveučilište Jurja Dobrile u Puli, Fakultet za odgojne i obrazovne znanosti, Ronjgova 1, HR-52100 Pula.

* Doc. dr. sc. Dijana Drandić, Istarsko veleučilište - Università Istriana di scienze applicate, Riva 4, HR-52100 Pula.

***: Doc. dr. sc. Lorena Lazarić, Sveučilište Jurja Dobrile u Puli, Fakultet za odgojne i obrazovne znanosti, Ronjgova 1, HR-52100 Pula. 


\section{Uvodna razmatranja ${ }^{1}$}

Polaskom u školu dijete ulazi u »novi svijet«, svijet škole u kojem će se vrjednovati njegov rad, sposobnosti, znanje. »Škola je prvi ozbiljan ispit samostalnosti, odgovornosti i ispunjavanja obveza. $\aleph^{2}$ Od pedagoške godine 2015./2016. u Republici Hrvatskoj za svu djecu školske obveznike obvezno je pohađanje programa predškole u godini prije polaska u osnovnu školu. Za djecu koja idu u dječji vrtić, program predškole integriran je u redoviti program predškolskog odgoja i obrazovanja dječjeg vrtića. Pravilnikom je definirano da se "program predškole provodi od 1 . listopada do 31 . svibnja, a ukupno traje 250 sati godišnje za djecu koja nisu polaznici redovitoga programa dječjega vrtića u skladu s organizacijom rada odgojno-obrazovne ustanove.$^{3}$ Time je obuhvaćenost djece predškolskim programima potpuna, a dječji vrtić je značajan element $u$ mreži podrške tijekom procesa prijelaza. ${ }^{4} \mathrm{Da}$ bi dijete polazak u školu i pohađanje škole započelo što bolje i sa što manje poteškoća, potrebno je u periodu pohađanja vrtića osigurati mu uvjete za razvijanje i unaprjeđivanje vještina, navika i kompetencija te stjecanje spoznaja i zadovoljavanje interesa.

Prema spomenutom pravilniku kompetencije koje dijete u godini dana prije polaska u osnovnu školu treba steći i/ili unaprijediti odnose se na komunikaciju na materinjem jeziku, elementarnu komunikaciju na stranim jezicima, matematičke kompetencije, osnovne kompetencije u prirodoslovlju i tehnologiji, digitalne kompetencije, socijalne i građanske kompetencije, inicijativnost i poduzetništvo, kulturnu svijest i izražavanje, motoričke kompetencije primjerene dobi te na način učenja. Stavovi prema učenju, kao što su upornost, pažnja, kreativnost, inicijativa, znatiželja i rješavanje problema, su također važni za školsku spremnost. Prema dosadašnjoj odgojno-obrazovnoj praksi, od djeteta predškolske dobi očekuje se da je pripremljeno za polazak u školu i da može odgovoriti na postavljene zahtjeve. ${ }^{5}$ Odgojitelji pripremaju djecu za prelazak u školu, a učitelji tu istu djecu sa svim njihovim različitostima u predznanju trebaju bez većih stresnih situacija primiti u prvi razred i omogućiti im uspješan prijelaz u novu okolinu. ${ }^{6}$

\footnotetext{
${ }^{1}$ Pojmovi koji se koriste u ovom radu, a koji imaju rodno značenje, bez obzira na to koriste li se u ženskom ili muškom rodu, na jednak način obuhvaćaju ženski i muški rod.

${ }^{2}$ Usp. B. STARC, Spremnost za školu, Dijete, vrtić, obitelj, 11 (2005) 39, 5-7, 5.

${ }_{3}^{3}$ Pravilnik o sadržaju i trajanju programa predškole, Ministarstvo znanosti, obrazovanja i sporta Republike Hrvatske, (2014), https://narodnenovine.nn.hr/clanci/sluzbeni/2014_09_107_2081. html (01.01.2021).

${ }^{4}$ Usp. I. SOMOLANJI TOKIĆ, Kompetencije učitelja i polazak djeteta u osnovnu školu u svjetlu nove kurikularne reforme, Školski vjesnik - časopis za pedagogijsku teoriju i praksu, 65 (2016) 3, 423-440.

${ }^{5}$ Usp. I. SOMOLANJI TOKIĆ, J. KRETIĆ MAJER, Dijete kao aktivni sudionik polaska u osnovnu školu, Život i škola - časopis za teoriju i praksu odgoja i obrazovanja, 61 (2015) 1, 103-110.

${ }^{6}$ Usp. M. ŠKROBO, S. ŠKROBO, A. TOLI, Priprema učitelja za prijem i polazak djeteta u osnovnu školu, Život i škola, 29 (2013) 1, 357-371.
} 
Pažnja predškolskog djeteta karakterizirana je spontanošću i nenamjernošću, a značajna je za pripremu djeteta za školsko učenje. ${ }^{7}$ Formiranje djetetove voljne pažnje usko je vezano uz povećavanje dječjih govornih sposobnosti. Spremnost za školu podrazumijeva tjelesnu, motoričku, spoznajnu, govornojezičnu spremnost, komunikaciju, emocionalnu i socijalnu spremnost te motiviranost djeteta, da bi se bez većih poteškoća prilagodilo zahtjevima škole. ${ }^{8}$ Naime, u toj dobi, osim obitelji, veliku ulogu u razvoju djeteta ima interakcija i druženje s vršnjacima, rad s odgojiteljima te neposredan kontakt s prirodnom i društvenom okolinom djeteta. Suvremena shvaćanja domena školske spremnosti sugeriraju visok stupanj povezanosti između domena, na primjer, čitanja i matematike. ${ }^{9}$

Mnogobrojna istraživanja o važnosti predčitalačkih ${ }^{10} \mathrm{i}$ predmatematičkih ${ }^{11}$ vještina djece predškolske dobi ukazala su na nekoliko značajnih činjenica koje utječu na ukupan razvoj i interakciju s okolinom. Naime, sposobnosti razumijevanja i govora te vještine čitanja i pisanja nisu odvojene sposobnosti, niti su uzastopni procesi, već se one, sukladno uzrastu i djetetovim sposobnostima, stječu tijekom razvoja i međusobno obogaćuju..$^{12}$ Istraživanja rane pismenosti u djece predškolske dobi uglavnom su provodili engleski autori. Utvrđeno je da djeca engleskog govornog područja počinju prije razlikovati i imenovati velika slova nego mala, brže usvajaju slova koja se lako vizualno razlikuju te bolje poznaju slova iz prve polovice abecede nego iz druge polovice te brže ovladaju onim slovima kod kojih postoji podudarnost u imenu i izgovoru slova. ${ }^{13}$ Istraživanja o predčitalačkoj pismenosti djece kojima je hrvatski jezik materinji ističu uvažavanje individualnih karakteristika svakog djeteta koje imaju utjecaj na

7 Usp. H. SELIMOVIĆ, E. KARIĆ, Učenje djece predškolske dobi, Metodički obzori, 6 (2011) 1, 145-160.

${ }^{8}$ Usp. P. L. SLOT, D. BLESES, P. JENSEN, Infants' and Toddlers' Language, Math and SocioEmotional Development, Evidence for Reciprocal Relations and Differential Gender and Age Effects. Front Psychol, 11 (2020) 580297, 1-12; Lj. LOVREKOVIĆ i dr., Ulazak u svijet škola vodič za roditelje, Velika Gorica, Centar za djecu, mlade i obitelj, 2015.

9 Usp. K. DENTON, E. GERMINO-HAUSKEN, America's Kindergartners (NCES 2000-070), Washington, Department of Education, National Center for Education Statistics, 2000.

${ }^{10}$ Usp. M. ČUDINA-OBRADOVIĆ, Čitanje prije škole: priručnik za roditelje i odgojitelje. Zagreb, Školska knjiga, 2002, 7; J. VIGNJEVIĆ, V. VELIČKI, D. VELIČKI, Understanding L1 instructional texts by pre-school children, Language, Individual \& Society - Journal of International Scientific Publications, 8 (2014) 80-91.

${ }^{11}$ Usp. M. ČUDINA-OBRADOVIĆ, Matematika prije škole: priručnik za roditelje i odgojitelje, Zagreb, Školska knjiga, 2008; Z. Marendić, Teorijski okvir razvoja matematičkih pojmova u dječjem vrtiću, Metodika matematike, 10 (2009) 1, 129-141.

${ }^{12}$ Usp. I. MARTINOVIĆ, I. STRIČEVIĆ, Slikovnica: prvi strukturirani čitateljski materijal namijenjen djetetu, Libellarium, 4 (2011) 1, 39-63.

${ }^{13}$ Usp. M.R. ELLEFSON, R. TREIMAN, B. KESSLER, Learning to Label Letters by Sounds or Names: A Comparison of England and the United States, Journal of Experimental Child Psychology, 102 (2009) 3, 323-341; https://doi.org/10.1016/j.jecp.2008.05.008. 
njegov jezični razvoj; ${ }^{14}$ važnost razvoja fonološke svijesti da se rečenica sastoji od riječi, riječ od slogova, a slogovi od fonema te početno čitanje i pisanje tiskanih i pisanih slova. ${ }^{15}$ Iz dostupnih rezultata istraživanja hrvatskih autora, vidljivo je da razine postignuća djece u predškolskoj dobi slijede već opisane principe postupnosti razvoja vještine čitanja i pisanja kod engleskih autora. Također, ističe se važnim provođenje aktivnosti koje uključuju rimu, radi poticanja fonemske svjesnosti, zatim smjer ovladavanja fonemskom svjesnošću, od vještine stapanja prema vještini raščlanjivanja, te redoslijed učenja slova. ${ }^{16}$

Djeca predškolske dobi sposobna su glasovno raščlaniti riječi i svrstati riječi prema početnom i završnom glasu, prepoznaju glasovne igre riječima, što će kasnije povezati s pisanim simbolima, te lakše prepoznaju univerzalna slova (npr. c, p, v, a i sl.) od prototipnih slova hrvatske latinice, složenih grafema (š, č, dž, lj). ${ }^{17}$ Ona pokazuju interes za upoznavanje slova i slaganje riječi, a najlakše uče i stječu predčitalačke vještine kroz igru i zabavu..$^{18}$ Odgojitelji bi stoga trebali, imajući u vidu lingvistički razvoj djeteta, strukturirati aktivnosti za predškolski uzrast kroz igru i pjesmu te čitanje slikovnica. Slikovnica je prvi izvor pisane riječi s kojom se dijete najranije susreće i važna je u razvoju predčitalačkih vještina. Autori koji slikovnicu opisuju kao najčešće posredovani materijal u aktivnostima čitanja, posebno ističu njezinu govorno-jezičnu funkciju. ${ }^{19}$ Čitanjem naglas razvojno primjerenih slikovnica, samostalno ili u društvu s vršnjacima, odgojiteljima ili roditeljima, potiče se razvoj govora, usvajanje i proširivanje rječnika, upoznavanje karakteristika teksta te način na koji tekst funkcionira, usvajanje sustava jezičnih oblika i načina kako se riječi oblikuju, usvajanje jezičnih pravila i gramatike te drugih predčitalačkih vještina. ${ }^{20}$

Dijete je od samog rođenja u interakciji s okolinom te spontano razvija slušanje i govor. ${ }^{21}$ Rana pismenost kod predškolske djece podrazumijeva sve ono

${ }^{14}$ Usp. V. BUDINSKI, I. LUJIĆ, Preschool Teachers' Opinions on the Methodology of Teaching Activities for Developing Pre-Reading and Pre-Writing Skills, Croatian Journal of Education Hrvatski časopis za odgoj i obrazovanje, 20 (2018), Sp. Ed. 2, 131-170.

${ }^{15}$ Usp. A. BEŽEN, V. BUDINSKI, M. KOLAR BILLEGE, Procjena fonološke svjesnosti učenika prvoga razreda kao preduvjet za početno čitanje i pisanje na hrvatskome jeziku, u: S. Blažetin (ur.), XI. međunarodni kroatistički znanstveni skup, Pečuh, Znanstveni zavod Hrvata u Mađarskoj, 2013, 221-231; J. KUVAČ KRALJEVIĆ, M. LENČEK, K. MATEŠIĆ, Phonological Awareness and Letter Knowledge. Indicators of Early Literacy in Croatian, Croatian Journal of Education, 21 (2019) 4, 1263-1293; M. LENČEK, M. UŽAREVIĆ, Rana pismenost - vrijednost procjene, Hrvatska revija za rehabilitacijska istraživanja, 52 (2016) 2, 42-59.

${ }^{16}$ Usp. Kuvač Kraljević, Lenček, Matešić, Phonological Awareness..., 1292.

${ }^{17}$ Usp. M. PERETIĆ, N. PADOVAN, L. KOLOGRANIĆ BELIĆ, Rana pismenost, u: J. Kuvač Kraljević, (ur.), Priručnik za prepoznavanje i obrazovanje djece s jezičnim teškoćama, Zagreb, Edukacijsko-rehabilitacijski fakultet Sveučilišta u Zagrebu, 2015, 52-62.

${ }^{18}$ Usp. M. PETEH, Svako slovo nešto novo, Zagreb, Alinea, 1999.

${ }^{19}$ Usp. I. MARTINOVIĆ, I. STRIČEVIĆ, Slikovnica. Prvi strukturirani čitateljski materijal namijenjen djetetu, Libellarium, 4 (2011) 1, 39-63.

${ }^{20}$ Usp. Martinović, Stričević, Slikovnica..., 53.

${ }^{21}$ Usp. S. B. KAMERMAN, School Readiness and International Developments in Early Childhood Education and Care, Encyclopedia on Early Childhood Development (2008), http:// 
što dijete u toj dobi zna i može u području čitanja i grafomotorike prije nego što postane sposobno samostalno čitati i pisati. Prije polaska u školu dijete bi trebalo savladati sve predčitalačke vještine, jer su one važne za učenje čitanja i stjecanje čitalačkih vještina. ${ }^{22}$ Povezujući predčitalačke i predmatematičke vještine, ${ }^{23}$ istraživanja su pokazala da matematičko predznanje više utječe na kasnije postignuće čitanja, dok čitanje manje utječe na kasnije razvijanje matematičkih vještina. Istraživanja predmatematičkih vještina djece/učenika u hrvatskom odgojno-obrazovnom području predškolskog i ranog školskog obrazovanja, vrlo su rijetka. Naime, predmatematičke vještine obuhvaćaju znanje, vještine i činjenice koje djeca usvajaju prije polaska u školu i važne su za njihovo kasnije razumijevanje matematike. ${ }^{24}$

Usvajanje vještina kao što su odnosi u prostoru, odnosi predmeta, svojstva predmeta, količina i pojam broja ${ }^{25}$ bitno određuju djetetov uspjeh u matematičkim vještinama tijekom školskog razdoblja. Osim vještine brojenja djeca predškolske dobi nauče i čitati brojeve. Većina šestogodišnjaka zna imenovati sve brojeve od 1 do 10 , dio šestogodišnjaka nauči i čitati brojeve između $10 \mathrm{i}$ 20 , dok mnogi od njih nauče i pisati neke od brojeva. ${ }^{26}$ Prije usvajanja matematičkih pojmova, predškolska djeca razvijaju svoje matematičko razmišljanje kroz aktivnosti pridruživanja (odabir zajedničke osobine predmeta), razvrstavanja (rastavljanje većeg skupa u nove skupove sa zajedničkim obilježjima), sparivanja (razvijanje brojenja kroz proces pridruživanja predmeta jedan na jedan) i nizanja, kao najsloženije aktivnosti jer dijete, osim obilježja mora činiti i usporedbe između predmeta koje slaže u nizu. ${ }^{27}$ Autori sugeriraju, kao i kod savladavanja predčitalačkih vještina, da djecu treba poticati na razvoj predmatematičkih vještina tijekom igre, svakodnevnih radnji i aktivnosti koje se provode u vrtiću. ${ }^{28}$

www.child-encyclopedia.com/documents/ KamermanANGxp-School.pdf (22.11.2020); K. L. SNOW, Integrative Views of the Domains of Child Function. Unifying school readiness', u: R. C. PIANTA i dr. (ur.), School Readiness and the Transition to Kindergarten in the Era of Accountability, Baltimore, Brookes Publishing, 2007, 197-216.

${ }^{22}$ Usp. S. A. STORCH, G. J. WHITEHURST, Oral language and code-related precursors to reading: evidence from a longitudinal structural model, Developmental Psychology, 38 (2002) 6, 934-947.

${ }^{23}$ Usp. G. J. DUNCAN i dr., School Readiness and Later Achievement, Developmental Psycho$\log y, 43$ (2006) 6, 1428-1446.

${ }^{24}$ Usp. D. H. CLEMENTS, J. SARAMA, Learning and Teaching Early Math. The Learning Trajectories approa Ch, New York, Routledge, 2014; D. GLASNOVIĆ GRACIN, Predmatematičke vještine, Matematika i škola, 11 (2010) 55, 200-205.

${ }^{25}$ Usp. M. FILIĆ, Z. KOLUNDŽIĆ, I. VIDOVIĆ, Jezične i govorne sposobnosti, predvještine čitanja, pisanja i matematike školskih obveznika 2017./2018. u Požeško-slavonskoj županiji, Logopedija, 7 (2017) 2, 49-55.

${ }^{26}$ Usp. M. GRDEN, Neke odrednice ranog matematičkog razvoja, diplomski rad, Sveučilište u Zagrebu, Edukacijsko-rehabilitacijski fakultet, 2018, 19.

${ }^{27}$ Usp. isto, 14.

${ }^{28}$ Usp. D. H. BAILEY i dr., State and trait effects on individual differences in children's mathematical development, Psychological Science, 25 (2014) 11, 2017-2026; N. C. JORDAN i dr., 
Dok se u predškolskoj dobi igra njeguje i potiče, jer je jedna od ključnih aktivnosti kroz koju djeca uče i spoznaju svijet, ${ }^{29} \mathrm{u}$ školskoj je dobi učitelji shvaćaju kao nepotrebnu, neozbiljnu aktivnost koja narušava strukturirano i formalno školsko okruženje. ${ }^{30}$ Neki hrvatski autori ukazuju na važnost i korisnost uporabe jezičnih igara, posebice u prvom razredu, jer one djeci mogu biti poticaj za razvoj jezične pismenosti i dobra priprema za proces učenja čitanja i pisanja. ${ }^{31} \mathrm{U}$ tom kontekstu, budući da je predškolska razina zapravo pripremna razina za osnovnu školu, godina u dječjem vrtiću prije polaska u školu shvaćena je kao »mala škola«. Takav pristup za cilj najčešće ima pripremanje djece na novo, školsko okruženje, gdje svako dijete mora usvojiti i zadovoljiti školska očekivanja. Prijelaz djece iz ustanove ranog i predškolskog odgoja i obrazovanja u osnovnu školu, iz perspektive učitelja, najčešće se odnosi na spremnost djece za školu, odnosno očekivanje da su djeca tijekom predškole zaista nešto i »naučila«. Dakle, model spremnosti djece za školu usmjeren je na ishode učenja kao procjene učenikove uspješnosti, iako je to u ranom i predškolskom sustavu neprimjeren način promatranja razvoja djeteta, a koje bi trebalo iskazati u obliku širih očekivanja. ${ }^{32}$

Stavovi učitelja o spremnosti za školu često se odnose na elementarno ovladavanje spomenutim predmatematičkim i predčitačkim vještinama. ${ }^{33}$ Osim konkretnih »školskih znanja«, kao važna kompetencija ističe se socio-emocionalna kompetencija djeteta. ${ }^{34}$ Različita istraživanja su pokazala da učitelji razredne nastave svoje procjene spremnosti djece za školu temelje na provjeri znanja čitanja, pisanja, početnih matematičkih pojmova i grafomotorike. ${ }^{35} \mathrm{Me}-$ đutim, učitelji bi se svakako trebali upoznati s radom predškole i aktivnostima koje odgojitelji provode i kako pripremaju djecu za polazak u osnovnu školu. ${ }^{36}$ Očekivanja učitelja često proizlaze iz nepoznavanja i/ili nerazumijevanja kuri-

Early math matters: kindergarten number competence and later mathematics outcomes, Developmental Psychology, 45 (2009) 3, 850-867.

${ }^{29}$ Usp. E. SLUNJSKI, M. LJUBETIĆ, Play and its Pedagogical Potential in a Preschool Institution, Croatian Journal of Education, 16 (2014) 1, 127-141.

${ }^{30}$ Usp. D. A. YEBOAH, Enhancing Transition from Early Childhood Phase to Primary Education. Evidence from the research literature, Early Years, 22 (2002) 1, 51-69.

${ }^{31}$ Usp. K. ALADROVIĆ SLOVAČEK i dr., Jezične igre kao poticaji u nastavi hrvatskoga jezika, u: V. Majdenić, I. Trtanj, V. Živković Zebec (ur.), Dijete i jezik danas. Razvoj pismenosti u materinskom i inom jeziku, Osijek, Sveučilište Josipa Jurja Strossmayjera u Osijeku i Fakultet za odgojne i obrazovne znanosti, 2019, 59-84; K. ALADROVIĆ SLOVAČEK, S. POLAK, Utjecaj čitanja na govorenje i pisanje u ranome učenju hrvatskoga jezika, u: A. Kos-Lajtman i dr. (ur.), Iskustva i perspektive ranoga učenja jezika i književnosti u suvremenom europskom kontekstu, Zagreb, UF - EMEE 2012, 2014, 53-70.

${ }^{32}$ Usp. E. SLUNJSKI, Izvan okvira - kvalitativni iskoraci u shvaćanju i oblikovanju predškolskog kurikuluma, Zagreb, Element, 2015, 23.

${ }^{33}$ Usp. M. ČUDINA-OBRADOVIĆ, Spremnost za školu. Višestrukost značenja pojma i njegova suvremena uporaba, Odgojne znanosti, 10 (2008) 2, 285-300.

${ }^{34}$ Usp. S. BROSTRÖM, Bridge to school, u: S. Dockett, A. MacDonald (ur.), Just Do Good Research. Commentary on the Work and Influence of Bob Perry, Peridot Education, 2016, 28-37.

${ }^{35}$ Usp. Čudina-Obradović, Spremnost..., 295.

${ }^{36}$ Usp. M. ŠKROBO, S. ŠKROBO, A. TOLIĆ, Priprema učitelja za prijem i polazak djeteta u osnovnu školu, Životi škola, 29 (2013) 1, 357-371. 
kuluma za rani i predškolski odgoj i obrazovanje, cilja i uloge dječjeg vrtića i predškole, radi čega spremnost za školu definiraju najčešće kroz odgovornost i spremnost djeteta u odnosu na zahtjeve škole. ${ }^{37}$ Postupak »školifikacije« predškole učitelji temelje na usvojenosti vještina, sposobnosti i znanja potrebnih za polazak, odnosno uspješan prijelaz iz rane i predškolske ustanove u osnovnoškolski sustav. ${ }^{38}$ Da bi učitelji dobili bolji uvid u kurikulume predškole i usvojena znanja i vještine, pedagozi često naglašavaju važnost međusobne suradnje i komunikacije odgojitelja i učitelja, planiranje zajedničkih aktivnosti i posjeta djece iz vrtića osnovnim školama. ${ }^{39}$

\section{Metodologija istraživanja}

\subsection{Cilj istraživanja}

Cilj rada bio je ispitati stavove učitelja od 1. do 4. razreda osnovne škole o spremnosti predškolske djece za školu, posebice kroz usvojenost predčitalačkih i predmatematičkih vještina.

\subsection{Istraživačke hipoteze}

U skladu s ciljem istraživanja stavova učitelja razredne nastave o spremnosti djece za školu i demografskim karakteristikama s obzirom na godine radnog iskustva učitelja te za provjeru razlika u stavovima postavljene su sljedeće hipoteze:

H1: Postoji statistički značajna razlika u stavovima učitelja kod vrjednovanja predčitalačkih vještina predškolske djece $\mathrm{s}$ obzirom na godine radnog iskustva učitelja u sustavu odgoja i obrazovanja.

H2: Postoji statistički značajna razlika u stavovima učitelja kod vrjednovanja predmatematičkih vještina predškolske djece s obzirom na godine radnog iskustva učitelja u sustavu odgoja i obrazovanja.

${ }^{37}$ Usp. W. L. CHAN, The transition from kindergarten to primary school, as experienced by teachers, parents and children in Hong Kong, Early Child Development and Care, 180 (2010) 7, 973-993.

${ }^{38}$ Usp. I. SMOLANJI TOKIĆ, Kurikulumske poveznice prijelaza djeteta iz ustanove ranoga odgoja i obrazovanja u školu, doktorska disertacija, Sveučilište u Zagrebu, Filozofski fakultet, 2018, 265-267.

${ }^{39}$ Usp. I. VISKOVIĆ, A. VIŠNJIĆ-JEVTIĆ, Transition as a shared responsibility, International Journal of Early Years Education, 28 (2020) 1, 1-15; https://doi.org/10.15516/cje.v20i0.3326; I. VISKOVIĆ, Transition Processes from Kindergarten to Primary School, Croatian Journal of Education, 20 (2018) 3, Sp. Ed., 51-75; J. EINARSDOTTIR, From Pre-School to Primary School. When Different Contexts Meet, Scandinavian Journal of Educational Research, 50 (2006) 2, 165-184; https://doi.org/10.1080/00313830600575965. 


\subsection{Sudionici istraživanja}

U istraživanju su sudjelovala 362 učitelja od 1. do 4. razreda osnovnih škola iz svih županija Republike Hrvatske. Prikupljanje podataka za potrebe ovog istraživanja provedeno je online tijekom 2020. godine pomoću alata Google Forms. Uzorak je bio prigodan, sudionici istraživanja su ujedno bili članovi grupa osnovnoškolskih učitelja na Facebooku te je poveznica za pristup anketnom upitniku podijeljena putem Facebooka. S obzirom na spol, dobili smo očekivani rezultat: deset ispitanika muškog je spola $(2,8 \%)$ te 352 ispitanika $(97,2 \%)$ ženskog spola. Karakteristike uzorka s obzirom na godine radnog iskustva pokazuju da je najveći broj ispitanika (38,4 \%) s manje od 5 godina radnog iskustva, $34 \%$ od 5 do15 godina, $12,7 \%$ od 15 do 25 godina, $16,3 \%$ od 25 do 35 godina, dok je svega $2,2 \%$ s 35 ili više godina iskustva u odgojno-obrazovnoj djelatnosti.

\subsection{Instrument istraživanja}

Ovaj rad je dio šireg istraživanja spremnosti djece za školu iz perspektive učitelja razredne nastave iz hrvatskog i talijanskog odgojno-obrazovnog sustava, provedenog 2020. godine. Za potrebe ovog ispitivanja o stavovima učitelja hrvatskih škola, konstruiran je upitnik Predčitalačka i predmatematička spremnost djece za školu.

Upitnik ima 13 tvrdnji, a učitelji trebaju iskazati svoje slaganje na skali Likertovog tipa s pet stupnjeva: 1 = uopće se ne slažem, 2 = ne slažem se, 3 = nemam jasno mišljenje, $4=$ slažem se i $5=$ u potpunosti se slažem. Skala za mjerenje Predčitalačka i predmatematička spremnost djece za školu ima dvije supskale koje prema stavovima učitelja utvrđuju vještine predškolske djece potrebne za spremnost za školu. Prva supskala procjenjuje predčitalačke vještine sa sedam varijabli, a druga supskala procjenjuje predmatematičke vještine sa šest varijabli. Rezultati upitnika za pojedinu supskalu dobivaju se na temelju aritmetičke sredine čestica supskale i kreću se u rasponu od 1 do 5 . Pouzdanost skale Predčitalačka i predmatematička spremnost djece za školu u ovom istraživanju iznosila je Cronbach $\alpha=0,749$, dok je za pojedine subskale za predčitalačke vještine iznosila $\alpha=0,801$, a za predmatematičke vještine $\alpha=0,779$.

Prilikom provođenja istraživanja poštivani su etički standardi: ispitanicima su dane pisane upute o načinu popunjavanja upitnika uz zajamčenu anonimnost, mogućnost odustajanja od daljnjeg davanja odgovora i objašnjenje da će podaci biti korišteni isključivo u znanstvene svrhe. Izračunani su osnovni deskriptivni parametri (minimalni i maksimalni rezultat Min. i Max.), aritmetička sredina (M) i standardna devijacija (SD). Za testiranje hipoteza na varijablama i korelacije između demografske varijable godine radnog iskustva i varijabli predčitalačkih i predmatematičkih vještina korišten je neparametrijski Spearmanov koeficijent korelacije. 


\section{Rezultati istraživanja i rasprava}

Rezultati deskriptivne statistike za supskalu stavova učitelja za predčitalačke vještine prikazani su u tablici 1 .

Tablica 1. Deskriptivna statistika varijabli predčitalačkih vještina

\begin{tabular}{|c|l|c|c|c|c|c|}
\hline & Djeca prilikom upisa u prvi razred trebaju... & $\mathbf{N}$ & Min. & Max. & M & SD \\
\hline 1 & čisto izgovarati sve glasove & 362 & 1 & 5 & 3,45 & 1,222 \\
\hline 2 & znati pravilno držati olovku (pisaći pribor) u ruci & 362 & 1 & 5 & 3,67 & 1,143 \\
\hline 3 & znati glasovnu analizu i sintezu riječi & 362 & 1 & 5 & 2,95 & 1,157 \\
\hline 4 & $\begin{array}{l}\text { imati razvijenu slušnu percepciju (»čuti« glas i } \\
\text { imenovati slovo) }\end{array}$ & 362 & 1 & 5 & 2,93 & 1,132 \\
\hline 5 & $\begin{array}{l}\text { imati razvijenu vizualnu percepciju (»prepoznati« } \\
\text { i pokazati slovo) }\end{array}$ & 362 & 1 & 5 & 2,69 & 1,073 \\
\hline 6 & znati pisati sva velika tiskana slova & 362 & 1 & 5 & 1,80 & 0,805 \\
\hline 7 & znati napisati svoje ime velikim tiskanim slovima & 362 & 1 & 5 & 3,24 & 1,244 \\
\hline
\end{tabular}

Iz tablice 1 vidljivo je da najvišu aritmetičku sredinu ima varijabla znati pravilno držati olovku, odnosno pisaći pribor u ruci $(\mathrm{M}=3,67 ; \mathrm{SD}=1,143)$, zatim slijedi varijabla čisto izgovarati sve glasove $(M=3,45 ; S D=1,222)$ te varijabla znati napisati svoje ime velikim tiskanim slovima $(\mathrm{M}=3,24 ; \mathrm{SD}=1,244)$. Rezultati pokazuju da učitelji procjenjuju predčitalačke vještine važnima za spremnost djece za školu. Tome u prilog govore i studije koje naglašavaju da priprema djece za polazak u školu obuhvaća adekvatnu razinu razvijenosti kako fizičkih, motoričkih, govornih, vještina, tako i zahtjeva vezanih uz adekvatan stupanj samostalnosti. ${ }^{40} \mathrm{Da}$ bi djeca savladala pisanje, moraju imati razvijenu motoriku (grubu i finu). Možemo smatrati da je dijete savladalo grafomotoričke vještine, odnosno sposobnosti koje se mjere u kontekstu početne spremnosti djeteta za polazak u školu, kada koristi dominantnu ruku za pisanje, pravilno drži olovku vrhovima prstiju te ima ispravan pritisak olovke na papir. ${ }^{41}$

Iako je činjenica da većina predškolaca prije polaska u školu zna pisati gotovo sva velika tiskana slova i većinu malih tiskanih slova, učitelji u našem istraživanju tu vještinu ne procjenjuju izrazito bitnom karakteristikom predčitalačkih vještina. Varijabla znati napisati sva velika tiskana slova $(M=1,80 ; S D=1,244)$ procijenjena je kao najmanje bitna vještina. $\mathrm{S}$ obzirom na to da djeca u prvom razredu svladavaju vještinu čitanja i pisanja, ${ }^{42}$ poučavanje početnog čitanja i pisanja potrebno je vremenski uskladiti s dinamikom učenja i njihova jezično-

\footnotetext{
${ }^{40}$ Usp. Lenček, Užarević, Rana pismenost..., 43.

${ }^{41}$ Usp. C. E. CAMERON i dr., Fine motor skills and executive function both contribute to kindergarten achievement, Child Development, 83 (2012) 4, 1229-1244; https://doi/abs/10.1111/ j.1467-8624.2012.01768.x.

${ }^{42}$ Usp. Bežen i dr., Procjena fonološke svjesnosti... u: Blažetin (ur.), nav. dj.
} 
ga razvoja. ${ }^{43}$ Završetkom prvoga razreda dijete će ovladati vještinom čitanja pa potom i pisanja. ${ }^{44}$ Istraživanja su pokazala da učitelji smatraju da je prvi razred razdoblje u kojem djeca ovladavaju početnom čitalačkom pismenošću i cjelokupnim procesom pismenog izražavanja (oblikovanjem standardnih školskih slova, primjenom pravopisne norme, gramatičkom, sintaksnom i leksičkom razinom).$^{45}$ Naime, vizualna percepcija usko je povezana s pažnjom i koncentracijom, ali i s grafomotoričkim vještinama koje će se dodatno razvijati tijekom prvog razreda, pa će jačanjem vizualne percepcije dijete bolje razumijevati, analizirati, povezivati, a time i lakše učiti. ${ }^{46}$ Rezultati našeg istraživanja to potvrđuju budući da se učitelji većinom ne slažu ili nemaju stav o tome trebaju li djeca prije polaska u školu znati glasovnu analizu ili sintezu jednosložnih $i$ dvosložnih riječi $(\mathrm{M}=2,95 ; \mathrm{SD}=1,157)$, kao ni trebaju li imati razvijenu vizualnu percepciju, »prepoznati« $i$ pokazati slovo $(\mathrm{M}=2,69 ; \mathrm{SD}=1,073)$ i imati razvijenu slušnu percepciju, »čuti« glas i imenovati slovo $(\mathrm{M}=2,93 ; \mathrm{SD}=1,132)$.

Druga supskala odnosila se na ispitivanje stavova učitelja prema usvajanju predmatematičkih vještina prije polaska u školu. Rezultati deskriptivne statistike za predmatematičke vještine prikazani su u tablici 2.

Tablica 2. Deskriptivna statistika varijabli predmatematičkih vještina

\begin{tabular}{|c|l|c|c|c|c|c|}
\hline \multicolumn{2}{|c|}{ Djeca prilikom upisa u prvi razred trebaju... } & N & Min. & Max. & M & SD \\
\hline 1 & znati prepoznati boje & 362 & 1 & 5 & 4,38 & 0,768 \\
\hline 2 & $\begin{array}{l}\text { razumjeti prostorne odnose (ispred, iza, gore, dolje, } \\
\text { na, u, lijevo, desno) }\end{array}$ & 362 & 1 & 5 & 3,80 & 1,129 \\
\hline 3 & znati brojati do 10 & 362 & 1 & 5 & 3,50 & 1,196 \\
\hline 4 & znati brojati do 20 & 362 & 1 & 5 & 2,63 & 1,142 \\
\hline 5 & znati pisati i prepoznati brojeve do 10 & 362 & 1 & 5 & 2,36 & 1,028 \\
\hline 6 & znati pisati i prepoznati brojeve do 20 & 362 & 1 & 5 & 1,99 & 0,798 \\
\hline
\end{tabular}

Rezultati istraživanja prikazani u tablici 2 pokazuju visoku potvrđenost varijable koja se odnosi na prepoznavanje boja $(\mathrm{M}=4,38 ; \mathrm{SD}=0,768)$, dok su nešto slabije procijenjene varijabla razumjeti prostorne odnose: ispred, iza, gore, dolje, na, u, lijevo, desno $(\mathrm{M}=3,80 ; \mathrm{SD}=1,129)$ i varijabla znati brojati do $10(\mathrm{M}=3,50$; $\mathrm{SD}=1,196)$.

\footnotetext{
${ }^{43}$ Usp. V. BUDINSKI, Početno čitanje i pisanje na hrvatskome jeziku, Zagreb, Profil Klett Učiteljski fakultet Sveučilišta u Zagrebu, 2019.

${ }^{44}$ Usp. Budinski, Početno čitanje..., 150.

${ }^{45}$ Usp. M. KOLAR BILLEGE, Teachers' Opinions on the Teaching Methodology for Standard School Scripts in Initial Reading and Writing in the Croatian Language, Croatian Journal of Education, 17 (2015) 2, 411-452, 441.

${ }^{46}$ Usp. I. GRUBIŠIĆ, R. PINJATELA, Utjecaj programa poticanja psihomotoričkog razvoja na vizualno-motoričku integraciju, motoričke sposobnosti i crtež čovjeka u predškolske djece, Školski vjesnik - časopis za pedagoška i školska pitanja, 68 (2020) 2, 518-526.
} 
U literaturi se predmatematičke vještine često povezuju s razvijenom grafomotorikom, odnosno finom motorikom koja obuhvaća kontrolu i koordinaciju ruku i prstiju, koja se navodi kao bolji pokazatelj sposobnosti ranog matematičkog učenja nego sposobnosti ranog čitanja. ${ }^{47} \mathrm{Na}$ temelju matematičkih pojmova, poput broja, oblika, i veličina, fina motorička vještina djeci pruža mogućnost vježbanja pisanja slova, brojanja predmeta i razvrstavanje predmeta $u$ slične kategorije. ${ }^{48}$ Usvojene fine motoričke sposobnosti omogućavaju djeci da automatski pišu slova i brojeve, razumiju matematičke pojmove i dekodiraju riječi. ${ }^{49}$

Prema nekim autorima, predmatematičke vještine prije polaska u školu odnose se na sposobnost razlikovanja parametara različitih veličina nekog predmeta, usvajanja pojma količine, grupiranja predmeta, imenovanja svih brojeva od 1 do 10, čitanja brojeva između 10 i 20 te razumijevanja prostornih odnosa..$^{50}$ Rezultati proizašli iz našeg istraživanja djelomično potvrđuju navedene teze. Naime, podaci o stavovima učitelja prema predmatematičkim vještinama i rezultati koje smo dobili ukazuju da najvišim procjenjuju prepoznavanje boja, razumijevanje prostornih odnosa i brojanja do 10, dok pisanje i prepoznavanje brojeva do 10 ( $\mathrm{M}=2,36 ; \mathrm{SD}=1,028)$, zbrajanje do $20(\mathrm{M}=2,63$; $\mathrm{SD}=1,142)$ procjenjuju kao nepotrebne vještine prije škole. Učitelji se uopće ne slažu da djeca prije polaska u školu trebaju znati pisati i prepoznavati brojeve do $20(\mathrm{M}=1,99$; $\mathrm{SD}=0,789$ ).

Rezultati u tablici 3 prikazuju Spearmanov koeficijent korelacije između godina radnog iskustva u odgojno-obrazovnoj djelatnosti i procjene predčitalačkih i predmatematičkih vještina djece nakon završetka predškole i pri upisu u prvi razred.

\footnotetext{
${ }^{47}$ Usp. N. J. PITCHFORD i dr., Fine Motor Skills Predict Maths Ability Better than They Predict Reading Ability in the Early Primary School Years, Frontiers in Psychology, 7 (2016) 1-17, br. 783; https://doi.org/10.3389/fpsyg.2016.00783.

${ }^{48}$ Usp. C. E. CAMERON i dr., How are motor skills linked to children's school performance and academic achievement?, Child Development Perspectives, 10 (2016) 2, 93-98; https://doi. org/10.1111/cdep.12168.

${ }^{49}$ Usp. D. R. Becker i dr., Behavioral self-regulation and executive function both predict visuomotor skills and early academic achievement, Early Childhood Research Quarterly, 29 (2014) 4, 411-424; http://dx.doi.org/10.1016/j.ecresq.2014.04.014.

${ }^{50}$ Usp. R. B. MARTIN i dr., Number and counting skills in kindergarten as predictors of grade 1 mathematical skills, Learning and Individual Differences, 34 (2014) 12-23; Grden, Neke odrednice..., 19-20.
} 
Tablica 3. Spearmanov koeficijent korelacije s obzirom na godine radnog iskustva učitelja i predčitalačke vještine $(N=362)$

\begin{tabular}{|c|c|c|c|c|c|c|c|c|c|}
\hline \multirow{2}{*}{\multicolumn{3}{|c|}{ Varijable }} & \multicolumn{7}{|c|}{ Predčitalačke vještine } \\
\hline & & & V1 & V2 & V3 & V4 & V5 & V6 & V7 \\
\hline \multirow{2}{*}{$\begin{array}{l}\text { Spearmanov } \\
\text { koeficijent } \\
\text { korelacije }\end{array}$} & \multirow{2}{*}{$\begin{array}{l}\text { Godine } \\
\text { radnog } \\
\text { iskustva }\end{array}$} & $\begin{array}{c}\text { Koeficijent } \\
\text { korelacije }\end{array}$ & 0,036 & 0,023 & 0,009 & 0,034 & 0,015 & 0,005 & 0,029 \\
\hline & & $\begin{array}{l}\text { Statistička } \\
\text { značajnost }\end{array}$ & 0,561 & 0,507 & 0,783 & 0,445 & 0,722 & 0,906 & 0,533 \\
\hline
\end{tabular}

Iz tablice 3 vidljivo je da ne postoji statistički značajna povezanost između godina radnog iskustva učitelja i procjene spremnosti djece za školu na temelju usvojenih predčitalačkih vještina prilikom polaska u prvi razred na svim varijablama skale predčitalačkih vještina. Bez obzira na radno iskustvo, učitelji smatraju važnim da djeca do prelaska iz predškole u školu, kao drugu razinu odgojno-obrazovnog procesa, trebaju usvojiti predčitalačke vještine: imati razvijenu slušnu percepciju (»čuti« glas i pokazati slovo) (V4); znati pravilno držati olovku (pisaći pribor) u ruci (V2); znati napisati svoje ime velikim tiskanim slovima (V7); čisto izgovarati sve glasove (V1); imati razvijenu vizualnu percepciju (»prepoznati« slovo $i$ imenovati glas) (V5); znati glasovnu analizu $i$ sintezu riječi (V3); znati pisati sva velika tiskana slova (V6), odnosno, postupno razviti vještine čitanja i pisanja sukladno svojim sposobnostima, da bi nastavili svoj obrazovni proces.

Tablica 4. Spearmanov koeficijent korelacije s obzirom na godine radnog iskustva učitelja i predmatematičke vještine ( $N=362)$

\begin{tabular}{|c|c|c|c|c|c|c|c|c|}
\hline \multicolumn{3}{|c|}{ Varijable } & \multicolumn{5}{c|}{ Predmatematičke vještine } \\
\cline { 4 - 9 } & V1 & V2 & V3 & V4 & V5 & V6 \\
\hline $\begin{array}{c}\text { Spearmanov } \\
\text { koeficijent } \\
\text { korelacije }\end{array}$ & $\begin{array}{c}\text { Godine radnog } \\
\text { iskustva }\end{array}$ & $\begin{array}{c}\text { Koeficijent } \\
\text { korelacije }\end{array}$ & 0,079 & 0,095 & 0,068 & 0,124 & 0,145 & 0,164 \\
\cline { 5 - 9 } & $\begin{array}{c}\text { Statistička } \\
\text { značajnost }\end{array}$ & 0,082 & 0,035 & 0,150 & 0,006 & 0,001 & 0,000 \\
\hline
\end{tabular}

Iz tablice 4 uočavamo da postoji statistički značajna povezanost između godina radnog iskustva učitelja i stavova učitelja o usvojenim predmatematičkim vještinama i to na slijedećim varijablama: znati pisati $i$ prepoznati brojeve do 20 (V6); znati pisati i prepoznati brojeve do 10 (V5); znati brojati do 20 (V4) i razumjeti prostorne odnose: ispred, iza, gore, dolje, na, u, lijevo, desno (V2). Na varijablama znati prepoznati boje (V1) i znati brojati do 10 (V3), nije uočena statistički značajna povezanost stavova učitelja i godina radnog iskustva.

Rezultati ovog istraživanja ukazuju također na to da učitelji razredne nastave s manje godina radnog iskustva procjenjuju nužnima za daljnji nastavak obrazovanja, odnosno prijelaz iz predškole u školu, stečene predmatematičke vještine razumijevanja prostornih odnosa, brojanja do 10 te pisanja i prepoznavanja 
brojeva do 20. Činjenica je da su predmatematičke vještine preduvjet za učenje matematike i važne su za matematičku uspješnost na kraju prvog razreda. ${ }^{51}$ Možemo pretpostaviti da se učitelji s manje godina radnog iskustva ne osjećaju dovoljno kompetentnima u metodičkim aktivnostima usvajanja početnih matematičkih pojmova i predmatematičkih vještina. Međutim, dobiveni rezultati ukazuju i na minimalna očekivanja učitelja s više godina radnog iskustva kod vrjednovanja usvojenih predmatematičkih vještina predškolskog djeteta, znati prepoznati boje (V1) i znati brojati do 10 (V3), oslanjajući se na svoje iskustvo u odgojno-obrazovnom procesu. U tom kontekstu, možda bi trebalo promisliti o dodatnim edukacijama učitelja s manje radnog iskustva koje bi obuhvaćale postupke procjenjivanja, planiranja adekvatnih aktivnosti i primjenu određenih didaktičko-metodičkih smjernica vezane za znanje, vještine i činjenice važne za njihovo kasnije razumijevanje matematike.

\section{Zaključak}

Cilj istraživanja bio je ispitati stavove učitelja razredne nastave o spremnosti predškolske djece za školu, posebice vezano uz usvajanje predčitalačkih i predmatematičkih vještina, te ispitati postoji li povezanost između stavova o predčitalačkim i predmatematičkim vještinama predškolaca i godina radnog iskustva učitelja u odgojno-obrazovnom sustavu hrvatskih škola. Postavljena hipoteza (H1) da postoji povezanost, odnosno, statistički značajna razlika u stavovima učitelja kod vrednovanja predčitalačkih vještina predškolske djece s obzirom na godine radnog iskustva učitelja u sustavu odgoja i obrazovanja nije potvrđena. Povezanost nije utvrđena jer učitelji, bez obzira na radno iskustvo, podjednako procjenjuju predčitalačke vještine djece, usvojene u predškoli, za prijelaz u školu. Nadalje, postavljena hipoteza (H2) da postoji povezanost, odnosno, statistički značajna razlika u stavovima učitelja kod vrjednovanja predmatematičkih vještina predškolske djece s obzirom na godine radnog iskustva učitelja u sustavu odgoja i obrazovanja, djelomično je prihvaćena. Rezultati pokazuju da su učitelji s manje godina radnog iskustva skloniji više vrednovati usvojenost vještine razumijevanja prostornih odnosa, brojanja do 10 te pisanja i prepoznavanja brojeva do 20 u predškoli u odnosu na učitelje s više radnog iskustva.

Učiteljima, posebice onima s manje godina radnog iskustva, bi trebalo osigurati upoznavanje s kurikulumima ranog i predškolskog odgoja, suradnju i posjete vrtićima i predškolama te, kroz neformalno učenje i cjeloživotno ob-

\footnotetext{
${ }^{51}$ Usp. M. ČUDINA-OBRADOVIĆ, Oblici matematičke pripremljenosti za školu i njena važnost za uspjeh u učenju matematike: prijedlog suvremenog modela, Bjelovarski učitelj, 8 (1990) 2-3, 52-60; M. ČUDINA-OBRADOVIĆ, Odrednice i posljedice matematičke pripremljenosti za školu, Napredak, 140 (1990) 3, 330-340.
} 
razovanje, razvoj profesionalnih kompetencija, radi uspješnog provođenja odgojno-obrazovnog procesa i ostvarivanja kognitivnog i emocionalnog razvoja djece u školi.

Ipak, rezultate dobivene ovim istraživanjem, koji će zasigurno poslužiti za bolje razumijevanje stavova učitelja o predčitalačkim i predmatematičkim vještinama djece prije polaska u školu, treba tumačiti s oprezom. Njihova ograničenja odnose se na procjenjivanje samo dijela vještina u procesu spremnosti djece za školu. Preporuke za buduća istraživanja odnose se na spremnost škola za djecu i spremnost obitelji i zajednica za školu te njihovu povezanost sa sociokulturnim kontekstom. 


\section{Sandra Kadum* - Dijana Drandić** - Lorena Lazarić**** \\ Children's Readiness for School from a Teacher's Perspective \\ Summary}

The aim of the paper was to examine the attitudes of teachers of primary education ( $1^{\text {st }}$ to $4^{\text {th }}$ grade) about children's readiness for school with an emphasis on the child's pre-reading and pre-mathematical skills. The participants of the research were 362 respondents, teachers of primary education from primary schools in the Republic of Croatia. Our research has shown that teachers highlight the following as the most important skills that children should acquire before starting school: graphomotor (correct handling of a pencil or other writing utensils), pre-reading (clear pronunciation of all voices) and pre-mathematical (colour recognition and understanding of spatial relations; in front, behind, up, down, on, in, left, right). No statistically significant difference was found in teachers' attitudes towards pre-reading skills in relation to years of work experience in teaching, but a statistically significant difference was found between the arithmetic means of most particles that examine the importance of pre-mathematical skills. In this context, recommendations for future research relate to the equipment of the school for quality educational work with children, the willingness of families and communities to cooperate with the school as well as their connection with the socio-cultural context.

Key words: pre-reading and pre- mathematical skills, preschool, readiness for school, student, teacher.

(na engl. prev. Viktor Vojnić)

* Sandra Kadum, PhD, Assis. Prof., Juraj Dobrila University of Pula, Faculty of Educational Sciences; Address: Ronjgova 1, HR-52100 Pula, Croatia; E-mail: skadum@unipu.hr.

**: Dijana Drandić, PhD, Assis. Prof., Istrian University of Applied Sciences, Riva 4, HR-52100 Pula, Croatia; E-mail: ddrandic@iv.hr.

***: Lorena Lazarić, PhD, Assis. Prof., Juraj Dobrila University of Pula, Faculty of Educational Sciences; Address: Ronjgova 1, HR-52100 Pula, Croatia; E-mail: llazaric@unipu.hr. 